УДК 343.23.343.3/7(477)

\author{
И. И. Чугуников
}

\title{
ОБЪЕКТ ПРЕСТУПЛЕНИЯ В СОВРЕМЕННОЙ УГОЛОВНО-ПРАВОВОЙ НАУКЕ: ТРАДИЦИИ И НОВАЦИИ
}

Еще несколько лет тому назад в науке уголовного права господствовало определение объекта преступления как общественных отношений, охраняемых уголовным законом от преступных посягательств. Аналогичный вывод можно встретить и в многочисленных изданиях последних лет [1]. В тоже время в современной уголовно-правовой доктрине активно формируется позиция, подвергающая такой взгляд на объект преступления интенсивной критике.

Так, по мнению С. Б. Гавриша, концепция объекта как общественных отношений является искусственной конструкцией с ярко выраженным идеологическим подходом. «С позиции теории объекта как общественных отношений получается, - пишет С. Б. Гавриш, - что уголовное право охраняет не материальные ценности и блага, жизнь, здоровье, окружающую среду и т.д., а наоборот, некую форму их проявления, те или иные связи между субъектами отношений, тогда как в действительности таким охраняемым объектом является «правое благо» как определенная ценность» $[2$, с. 64-65].

В. М. Трубников, не отказываясь, по сути, от понимания объекта как общественных отношений, предлагает назвать их «социальной оболочкой» и представить в виде первичного объекта преступных посягательств, а реальные объекты - в виде вторичных объектов, которые находятся внутри социальной оболочки [3, с. 81-87].

В. А. Туляков приходит к выводу о необходимости признания объектом преступления конкретных физических лиц или их социальных общностей, а предметом преступления - социальные блага, которые принадлежат этим лицам [4, с. 237]. С этой позицией, хотя и с определенными оговорками, согласен и В. П. Емельянов: «Это в целом правильное представление об объекте преступления требует некоторых уточнений, поскольку не каждое преступление посягает непосредственно на чело- 
века. Оно может причинить ему вред и опосредовано, путем воздействия на условия его жизни и окружающую среду. Совершая преступление, виновный непосредственно посягает не только на людей, но и на те или иные разновидности, аспекты, проявления жизни, деятельности человека, коллективов, общества, их безопасность, условия существования и функционирования, иначе говоря, на конкретные сферы жизнедеятельности людей, которые охраняются уголовным законом и которые выступают как непосредственные объекты преступлений, как реальные явления действительности [5, с. 7-11].

Аналогичная тенденция, связанная с ревизией традиционной концепции объекта преступления, наблюдается и в уголовно-правовой теории других стран постсоветского пространства. Здесь одним из первых, кто выступил против понимания объекта преступления как общественных отношений, был А. В. Наумов. По его мнению, эта теория в некоторых случаях (особенно что касается преступлений против личности) «не срабатывает», поскольку марксистское понимание человека «как совокупности общественных отношений» умаляет «абсолютную ценность человека как биологического существа, жизни как биологического явления вообще», что, в конце концов, превращает человека из самостоятельной абсолютной ценности в носителя общественных отношений. Определяя содержание объекта преступления А. В. Наумов возвращается к теории правового блага, которая была создана еще в конце XIX столетия в рамках классической и социологической школ уголовного права и предлагала признать объектом преступления «те блага (интересы), на которые посягает преступное деяние и которые охраняются уголовным законом» $[6$, с. 147,149$]$. Еще более категоричен в этом вопpoce A. Н. Игнатов, который в отличие от А. Н. Наумова, только поставившего под сомнение универсальность традиционной концепции объекта, считает, что сегодня, когда отпала необходимость придерживаться господствующей марксисткой терминологии, а для обоснования позиции недостаточно ссылок на «руководящие источники», устоявшееся в советской уголовно-правовой литературе использование для определения объекта преступления социолого-философской категории «общественные отношения» является нецелесообразным. Если в свое время и считалось, что не могут рассматриваться как объект преступления люди, орудия, способы производства и иные материальные блага (поскольку K. Маркс указывал, что «преступное содержание деяния заключается не в посягательстве на лес, как нечто материальное, а в посягательстве на его нерв - на право собственности»), то сегодня этот аргумент убедительным не выглядит. Поэтому логичнее использовать нейтральное понятие «правовое благо», позволяющее характеризировать «вещественную, предметную и материальную природу» объекта преступления [7, c. 103-104].

Позицию А. Н. Игнатова полностью разделяет и С. Расторопов. «Как представляется, - указывает автор, - сформировавшийся в недрах со- 
ветской школы науки уголовного права взгляд на проблему объекта преступления не совсем пригоден для удовлетворения современных социальных потребностей, так как сложился в отрыве от реальной жизни. Есть все основания утверждать, что традиционное понимание объекта преступления основано на абстрактных уморозительных идеологических постулатах, искусственно внедренных в нашу действительность, а потому нуждается в переосмыслении.

Интерес представляет, прежде всего, концепция «объект - правовое благо как определенная ценность» [8, с. 40].

На фоне довольно жесткой критики традиционной трактовки объекта преступления и возрастающего количества предложений о необходимости возврата к теории объекта как правового блага, в постсоветской уголовно-правовой доктрине, естественно, не могла не появиться точка зрения, сводящая понятие объекта преступления к человеку. Эта позиция нашла отражение в монографическом исследовании Г. П. Новоселова, который приходит к выводу о том, что объектом каждого преступления являются люди - индивиды, их малые или большие группы (объединения), а также общество в целом, а материальные или нематериальные ценности, по поводу которых складываются отношения между этими лицами и которые А. В. Наумов, А. Н. Игнатов, С. Расторопов и др. называют правовыми благами, являются предметом преступления [9, с. 53-64].

Попытку систематизировать аргументы оппонентов теории объекта как общественных отношений в украинской уголовно-правовой литературе предпринял Е. В. Фесенко. Так или иначе, они сводятся к следующим положениям:

1) объектом преступления, с учетом характера и содержания общественных отношений, в итоге признавалась по сути политическая категория: преступный результат оценивался, прежде всего, сквозь призму господствующих отношений, с оглядкой на социальный, политический вред обществу и его институтам;

2) абстрактность и расплывчатость понятия «общественные отношения»;

3) учение об общественных отношениях как объекте преступления содержит положения, разрешаемые приверженцами этой теории крайне противоречиво. В частности, отсутствует единство мнений относительно структуры общественных отношений;

4) концепция определения объекта как общественных отношений не совсем соответствует современным взглядам относительно оценки социальных ценностей, которые берет под охрану уголовный закон. Существенным ее недостатком является определенное преувеличение значения категории «публичного» по отношению к категории «частного» в сфере социальной жизни. В связи с этим человек с его потребностями, интересами, правами отходил на второй план [10, с. 42-47].

Сам Е. В. Фесенко приходит к выводу, что объект преступления можно определить как ценности, охраняемые уголовным законом, против 
которых направлено преступное деяние и которым оно может причинить или причиняет вред. Ценности, по его мнению, - это разнообразные объекты материального мира, в частности, и сам человек, которые имеют существенное позитивное значение для отдельных лиц, социальных групп и общества в целом. Поэтому они охраняются нормами различных отраслей права, а наиболее важные из них берет под охрану уголовное законодательство [10, с. 51].

Позицию «объект преступления - социальные ценности» разделяет и целый ряд других украинских ученых, в частности, П. П. Андрушко [11; 12], В. Т. Дзюба [13], С. Я. Лиховая [14].

Предпримем попытку анализа предлагаемых в уголовно-правовой литературе новелл, касающихся учения об объекте преступления.

Прежде всего, хотелось бы полностью разделить сетования сторонников «новых» подходов к определению понятия объекта преступления, касающихся незаслуженного забвения как собственного исторического опыта, так и опыта других стран. Так, например, С. Расторопов отмечает следующее: «Объектом преступления в дореволюционной России признавался отдельно взятый человек или какое-то множество лиц, представляющих собой в любом цивилизованном обществе наивысшую ценность. Наряду с этим существовала теория объекта преступного деяния как правового блага, согласно которой объектом уголовно-правовой охраны назывались жизнь, здоровье, собственность и другие ценности. В западноевропейской науке уголовного права, кроме всего прочего, объектом преступления назывались также субъективные права лица, уголовно-правовые нормы в их реальном существовании, защищаемые правовыми нормами жизненные интересы и другие подобные явления. Однако все вышеуказанные концепции объекта преступления не стали в период существования советского государства предметом пристального внимания со стороны отечественных ученых, а были отвергнуты как буржуазные и реакционные» [8, с. 38].

Абсолютно справедливое замечание - одно непонятно: почему же тогда все достижения советской уголовно-правовой науки в анализируемом вопросе, затраченные ею усилия по исследованию феномена общественных отношений и их результаты отвергаются сегодня с необыкновенной легкостью?

Фундаментальные работы, посвященные объекту преступления, признаются насквозь заидеологизированными, а их авторы объявляются пленниками «длительное время внедрявшихся в юридическую науку априорных и абстрактных штампов и шаблонов» [15, с. 5]. Действительно, официальная идеология требовала в первую очередь обеспечения всеми способами безопасности нового социального порядка и рассмотрения любого уголовно-правового конфликта прежде всего и главным образом с классовых позиций. Поэтому ни одна работа по праву, в том числе и уголовному, не могла обойтись без ссылок на «первоисточники» и руководящие партийные документы. Однако утверждение о том, что, 
например, Б. С. Никифоров, Н.И.Коржанский, В.К.Глистин, В. Я. Таций и др., всерьез искали обоснования собственных взглядов на объект преступления в решениях очередного съезда партии, постановлениях пленумов ЦК или трудах классиков марксизма-ленинизма, с нашей точки зрения, мягко говоря, наивно. Наличием, пусть даже и большого количества, идеологических нюансов содержание их трудов явно не исчерпывалось. Так, например, вряд ли заслуживает сегодня поддержки тезис Н. И. Коржанского о том, что в «общественных отношениях закрепляются и реализуются прежде всего интересы господствующих классов» [16, с. 113]. В то же время трактовка объекта преступления как обеспечиваемого обществом соответствующего его интересам поведения или состояния субъектов общественных отношений [16, с. 117], как представляется, актуальности не утратила.

В любую историческую эпоху магистральное направление развития уголовного права определяет некая доминирующая идея, своего рода «фишка», рожденная на определенном этапе развития общества. Так «фишкой» советского периода была идея примата общественного над частным, первоочередной защиты государственных интересов. Этой идее был подчинен и законотворческий процесс. Эпоха независимости породила новую «фишку» - идею о необходимости приведения отечественного уголовного законодательства в соответствие с европейскими стандартами. Где они изложены и как выглядят пока неясно. Но очевидно другое - во главе угла должен находиться человек. Законодатель подхватывает эту идею и начинается интенсивная ломка «старой»и, конечно, «реакционной» нормативной базы. Конституции новых независимых государств провозглашают человека, его жизнь и здоровье, честь и достоинство, неприкосновенность и безопасность наивысшей социальной ценностью (ст. 3 Конституции Украины), а УК некоторых республик (например, Российской Федерации, Республики Армения), следуя европейским «стандартам», перемещают преступления против жизни и здоровья личности на первое место в системе Особенной части. Но революции, к сожалению, не произошло. Более того, оказывается, что обеспечить надлежащую защиту наивысшей социальной ценности абсолютно невозможно в условиях, когда слабы и недееспособны государственные институции. Кроме того, выясняется, что та же Европа придерживается и других «стандартов». Так, например, УК Бельгии предусматривает ответственность за преступления против жизни только в восьмом разделе, а УК ФРГ - в шестнадцатом. Однако страсти не утихают. Пресловутый антропологический подход набирает обороты, вытесняя из отечественной уголовно-правовой доктрины малейшие этатистские проявления.

Хотелось бы обратить внимание еще на один аспект, связанный с идеей приведения национального уголовного законодательства в соответствие с европейскими «стандартами». Здесь уместно будет привести наименования некоторых разделов Особенной части УК европейских государств. Так, например, раздел II УК Швейцарии предусматривает 
ответственность за преступные деяния против имущества, раздел IX за преступления против общественного транспорта, раздел XIII - за преступления против обороны страны, а раздел XVIII - за преступные деяния против служебных обязанностей.

Раздел VIII УК Австрии объявляет наказуемыми преступные деяния против покоя умерших, раздел XII - деяния против достоверности документов, а раздел XVII - деяния против вооруженных сил. Не хочется думать, что Особенная часть УК Украины когда-нибудь будет приведена в соответствии с такими «стандартами».

Қак уже отмечалось, приведенные выше «новые» подходы в определении объекта преступления давно и хорошо известны, в том числе и отечественной школе уголовного права. Поэтому фактически в каждой современной работе, посвященной объекту преступления, авторы так или иначе в обоснование своей позиции приводят взгляды Н.С. Таганцева, А. Ф. Кистяковского, Л. С. Белогриц-Котляревского и других представителей уголовно-правовой науки досоветского периода. Однако, как представляется, исследование проблемы объекта в исторической ретроспективе зачастую носит, во-первых, довольно фрагментарный, а во-вторых, - односторонний характер, поскольку те или иные выдержки из работ классиков используются в нужном для автора направлении.

Так, например, С. Б. Гавриш, пришедший к формуле «объект - правовое благо» [17, с. 72], аргументирует свой вывод следующими ссылками: «Н. С. Таганцев писал: «Определяя преступное деяние как посягательство на норму в ее реальном бытии или как деяние, посягающее на отраженный нормою юридический интерес, мы тем самым устанавливаем и понятие об объекте преступного посягательства. Л. С. БелогрицКотляревский отмечал, что «преступление есть прежде всего нарушение закона или, говоря точнее, правовой нормы, регулирующей отношения людей друг к другу или к юридическим установлениям, совокупность которых образует правопорядок. Но преступление, нарушая нормы, т. е. абстрактные запреты или веления закона, вместе с тем необходимо разрушает те реальные блага или интересы, для которых эти нормы существуют.

...Таким образом, объектом преступления с формальной стороны является норма, а с материальной - те жизненные интересы или блага, которые этими нормами охраняются» [17, с. 11].

В. П. Емельянову, утверждающему, что объектом преступления является не что иное, как охраняемые уголовным законом конкретные сферы жизнедеятельности людей [18, с. 67], ближе высказывание А. Ф. Кистяковского: «Объектом преступления может быть, вообще говоря, только человек со всеми правами, учреждениями, которые им как существом общественным создаются. Посему кроме жизни, здоровья, свободы, чести, как более или менее основных объектов преступления, так сказать, созданных самою природою, таковыми являются также вещи, животные, даже известный строй мыслей» [18, с. 66-67]. 
В этой связи, как представляется, будет вполне обоснованным изложение позиций цитируемых авторов в более пространной редакции.

Н. С. Таганцев в работе «О преступлениях против жизни по русскому праву» так определяет понятие объекта: «Предмет или объект преступления вообще составляют известные юридические отношения, охраняемые государством и угрожаемые или нарушаемые действием виновного; в данном случае подобным отношением является неприкосновенность жизни членов общества» [19, с. 17]. Весьма показателен в интересующем нас аспекте критерий, который предлагает автор для разграничения убийства и самоубийства: «Так как преступление есть нарушение или посягательство на юридические отношения, то о нем и может возникнуть вопрос только там, где существуют эти правоотношения, поэтому, признавая, что объектом убийства является жизнь человеческая, мы тем не менее не можем с юридической точки зрения распространять понятие убийства на самоубийство, потому как к самому себе человек не состоит в каких-либо правоотношениях, которые бы он мог нарушить своим действием» $[19$, с. 18]. Справедливости ради отметим и такой тезис Н. С. Таганцева: «Так как в обществе под охраною правового порядка может находиться только человек с его благами и правами...» [19, с. 17]. Однако, это только первая часть тезиса, а заканчивается фраза так: «...то, следовательно, и объектом убийства может быть только жизнь человека. Всякое прекращение чьего-либо органического существования, которое мы на обыкновенном житейском языке называем умерщвлением, не может быть названо убийством в глазах закона. Если же подобные деяния иногда и воспрещаются законом под страхом уголовной ответственности, то совершенно с иной точки зрения. В этих случаях закон преследует или причинение ущерба частному лицу, посягательство на право собственности, как, например, истребление животных, находящихся в чьем-либо владении; или же нарушение полицейских предписаний, как, например, уничтожение рыбы или дичи в недозволенное время и недозволенным способом, истребление животных редких и т. п.» [19, с. 17].

Совершенно очевидно, что рассматривая человека с его благами и правами в качестве единственного объекта уголовно-правовой охраны, Н. С. Таганцев всего лишь проводит разграничение между убийством и «умерщвлением иных органических существований» и более ничего.

Ничем принципиальным от позиции Н. С. Таганцева не отличаются и взгляды Л. С. Белогриц-Котляревского, если только часто используемый тезис из его работы не вырывать из общего контекста: «Преступление есть прежде всего нарушение закона или, говоря точнее, правовой нормы, регулирующей отношения людей или друг к другу, или к юридическим установлениям, совокупность которых образует правопорядок. Но преступление, нарушая нормы, то есть абстрактные запреты или веления закона, вместе с тем необходимо разрушает те реальные блага или интересы, для которых эти нормы существуют. Нарушая норму 
«не укради», вор вместе с тем разрушает чье-либо имущественное благо. Таким образом, объектом преступления с формальной стороны является норма, а с материальной - те жизненные интересы или блага, которые этими нормами охраняются. Так как нормы предназначены регулировать отношения людей или друг к другу, или к юридическим установлениям, то очевидно, что область преступного должна ограничиваться этими двумя категориями отношений; отношение же всякого другого рода отсюда должны быть исключены. На этом основании нельзя считать преступлением посягательство или разрушение своих собственных благ, или, что-то же, субъект преступления не может в одно и то же время быть и объектом его; таковы следующие деяния: самоубийство, самоизуродование, личные безнравственные действия и повреждения своих имущественных благ» [20, с. 161-162]. Как представляется, комментарии излишни.

Приведем точку зрения В. Спасовича, также довольно часто цитируемого представителями «новых» подходов к определению объекта преступления, которые сводят это понятие к человеку.

«Преступление, - отмечает В. Спасович, - есть посягательство на чье-либо право, охраняемое государством посредством наказаний. Из этого определения вытекают два весьма важных последствия:

1) так как право бывает всегда чье-нибудь, а владельцами или субъектами прав могут быть только лица человеческие единичные или собирательные, то и преступление может быть совершено только против какого-нибудь лица, следовательно, предметом преступления может быть только лицо; 2) коль скоро по каким-нибудь причинам государство отнимает от известного права свою защиту, то нарушение его перестает быть бесправием и не подлежит уже ведению уголовного правосудия» [21, с. 94]. Далее В. Спасович конкретизирует это положение указывая, что предметом преступления может быть только человеческое лицо с его правами, а не вещь, не животное, не отвлеченное понятие [21, с. 94]. Несложно заметить, что рассуждения В. Спасовича, как и рассуждения Н. С. Таганцева и Л. С. Белогриц-Котляревского, основываются на анализе человека не как вида «органического существования», а как некого социального продукта, проще говоря, как субъекта определенных социальных отношений.

«Право, - продолжает В. Спасович, - может принадлежать как лицам единичным, физическим, так и лицам собирательным, юридическим, то есть целым группам и сочетаниям, состоящим из лиц физических, различной величины, назначения, размеров.

Таким образом, предметом преступления может быть частное лицо, семья, сословие, церковь, совокупность лиц, находящихся в известной местности, или публика, государство и его правительство, со всеми органами этого правительства. Собственно говоря, государство, как организм поддерживающий совокупность всех юридических отношений между членами общества, не бывает никогда в целом своем объеме 
прямым и непосредственным предметом преступления; преступление касается его только посредственно, через отрицание какого-нибудь отдельного, особенного права. Но, с другой стороны, характеристическую черту в каждом уголовном преступлении составляет то обстоятельство, что его вредные последствия идут дальше того права, которое нарушено, и потрясают весь общественный порядок. Таким образом можно сказать, что всякое уголовное преступление против лица юридического государства и что непосредственным его объектом есть чье-нибудь определенное право, а посредственным - целое правосостояние, то есть быт государственный» [21, с. 96].

В рассуждениях Н. Д. Сергиевского также присутствует весьма отчетливое понимание двойственности объекта преступного воздействия, неизбежно заключающего в себе моменты вреда отдельным лицам и всему обществу, в силу чего всякое преступное деяние, заключая в себе вред или опасность известным конкретным благам или интересам - непосредственным предметам посягательства, в то же время является посягательством на отвлеченный интерес всего общежития [22, с. 233-234].

Анализ приведенных положений позволяет сделать, по крайней мере, один недвусмысленный вывод - отечественная уголовно-правовая доктрина досоветского периода настаивала на признании в качестве объекта правоохраны не каждого интереса индивида или группы, а только такого, который может иметь общественное значение [23, с. 34-35].

«Уголовно-наказуемымъ, - писал Н. С. Таганцев, - почитается дьяніе, посягающее на такой охраненный нормою интересъ жизни, который въ данной странъ, въ данное время, признается столь существеннымъ, что государство, въ виду недостаточности другихъ мъръ охраны, угрожаеть посягательству на него наказаніемъ» [24, с. 647].

Таким образом, уже тогда криминалисты задумывались над тем, что за причинением преступником вреда потерпевшему (объекту) скрывается нечто большее - нарушение необходимых условий общежития. Кстати сказать, сведение объекта преступного посягательства к чьему-либо праву, по-видимому, не совсем устраивало даже самого А. Фейербаха. «Кто преступает правомерные границы свободы, тот нарушает права, делает оскорбление, обиду, вред. Кто нарушает свободу, утвержденную гражданским договором и обеспеченную наказательными законами, тот делает преступление, которое по сему в дальнейшем смысле есть повреждение или нарушение под наказательным законом состоящее, или деяние по закону наказанием вперед угрожаемое и правам другого противоборствующее. Оскорбление, обиды даже и вне Государства возможны; преступления же только в Государстве» [25, с. 21].

«Поскольку сохранение прав вообще есть цель наказательных законов, то как права подданных, так и права, принадлежащие Государству (как нравственному лицу), составляют предмет защищающего их учреждения. И так, кто преступая наказательный закон, нарушает непосредственно права государства, тот делает публичное преступление (госу- 
дарственное преступление): но ежели право подданного есть непосредственный предмет нарушения, то это значит приватное или частное преступление» [25, с. 23].

Неудивительно, потому что и западная уголовно-правовая доктрина тоже была нацелена на поиск объекта как чего-либо более «существенного», чем приватные интересы индивида. Так, по мнению Листа, «преступленіе может быть опредълено (по существу), какъ вмъняемое, противоправное дъйствіе, которое всльдствіе своей особой опасности для строя правовыхъ благъ обложено наказаніемъ» [24, с. 647].

Қак здесь не согласиться с А. И. Бойцовым, который отмечает следующее: «Конечно по внешней видимости похититель вступает во взаимодействие с вещью, а убийца - с человеческим телом, которые таким образом вроде бы и становятся объектами уголовно-правовой охраны. Однако имущество охраняют сторожа, а людей - телохранители. Органы же уголовной юстиции стоят на страже правопорядка как такого порядка отношений между людьми, который основан на праве, т. е. в конечном счете охраняют нечто большее - господствующий порядок общественных отношений, системно структурирующих общество и не дающих ему сорваться в бездну хаоса и самоуничтожения. А посему оправдано ли возвращение к осмыслению проблемы на уровне пения об увиденном? Оправдано ли такое возвращение к «истокам», когда потрачено столько усилий, чтобы понять существо этой проблемы?» [26, с. 28-29].

Итак, отечественная уголовно-правовая доктрина (главным образом она, поскольку в доктрине западной учение об объекте дальнейшего развития так и не получило), хотя и не смогла преодолеть сковывающие ее рамки права (так или иначе преступление сводилось к нарушению норм положительного права, определяющих юридический строй общежития, заключающийся в необходимости соблюдения установленных законом правил жизни и деятельности), все же на рубеже XIX-XX вв. вплотную подошла к решению проблемы объекта (который пока отождествлялся с предметом и не был структурирован) преступления. Очевидно и другое. Если отбросить целый ряд идеологических нюансов, которыми изобиловала советская наука уголовного права, то между «юридическими отношениями», «отношениями людей друг к другу или к юридическим установлениям», «правосостоянием как бытом государственным» и «порядком общественных отношений» вполне можно усмотреть параллели. А это значит, что уголовно-правовая теория советского периода не была столь уж независимой от дореволюционного уголовноправового наследия и далеко не все ею было отвергнуто. Қак раз наоборот, взятый за основу порядок социальных отношений сначала ассоциируется с порядком, соответствующим интересам трудящихся масс и обусловленным диктатурой пролетариата, а впоследствии с социалистическим социальным порядком, который должен был быть преобразован в коммунистический социальный порядок «товарищеского сотрудниче- 
ства и взаимной поддержки» [27, с. 275]. По большому счету, советская доктрина никогда, по сути, не отвергала дореволюционную трактовку преступления как «констатированного законодательством вредоносного посягательства на жизненные условия общества» [28, с. 357]. Ее не устраивало представление об обществе как едином целом. Так, например, Н. Д. Дурманов отмечал следующее: «Социологи, а также и некоторые представители классической школы, говорят о преступлении как деянии, представляющем объективную опасность для общества, но попытки их определить характер этой опасности поражают своей беспомощностью, так как они стараются замаскировать классовую природу преступления»[29, с. 87].

Вот, собственно, и вся критика.

В современных условиях целиком понятно стремление многих ученых всячески откреститься от марксистко-ленинского наследия с его гипертрофированным пониманием роли общественного над личным и трактовкой личности как совокупности общественных отношений. Именно этим и была обусловлена излишняя отторженность от индивида в работах сторонников понимания объекта преступления как общественных отношений. Отсюда и интенсивный научный поиск нового «достойного» духу времени термина. Однако, как представляется, дело заключается не в терминологии, а в существе вопроса. Кстати говоря, это обстоятельство признается и приверженцами «новых» подходов к определению понятия преступления. Так, например, А. Э. Жалинский отмечает следующее: «Можно легко примириться с упорным употреблением бессодержательного понятия «общественные отношения», если кому-то употреблявшийся еще Н. С. Таганцевым термин «правовое благо» не нравится. Но защищаемое благо должно быть описано в законе, в решениях судов и в правовой доктрине так, чтобы можно было понять, в чем оно состоит, насколько оно ценно, требуя для охраны столь больших издержек, какова его уязвимость, как оно может быть умалено [30, с. 342].

Основное предназначение правовых предписаний - регламентировать жизнь социума, устанавливая границы дозволенного. Критерием деления права на отрасли, наряду с методом правового регулирования, выступают определенные сферы социальных отношений. «Совокупность общественных отношений, регулирование которых осуществляют правовые нормы, и поведение субъектов социальной активности, то есть участников таких отношений, составляют предмет правового регулирования. Правовые нормы направлены на установление и обеспечение устойчивости общественных отношений» [31, с. 130] - резонно замечают авторы учебного курса «Общетеоретическая юриспруденция» под редакцией Ю. Н. Оборотова. В процессе действия так называемых «созидательных» отраслей права (конституционного, гражданского, хозяйственного и т. д.) устанавливается определенный порядок сосуществования индивидов в пределах социума, который позволяет разрешать возникающие коллизии между субъектами теми способами, в которых за- 
интересованы государство и общество в целом. Именно этот порядок и является объектом уголовно-правовой охраны и не столь важно при этом как его назвать: «общественные отношения», «социальная оболочка» или «сферы жизнедеятельности». Так, например, сферу хозяйственных отношений согласно ч. 4 ст. 3 Хозяйственного кодекса Украины составляют хозяйственно-производственные, организационно-хозяйственные и внутрихозяйственные отношения. В результате их регламентации хозяйственным законодательством устанавливается определенный порядок осуществления хозяйственной деятельности, то есть деятельности субъектов хозяйствования в сфере общественного производства, направленной на изготовление и реализацию продукции, выполнение работ либо оказание услуг стоимостного характера, имеющих ценовую определенность (ч. 1 ст. 3 Хозяйственного кодекса Украины). В этой связи вполне естественным является предписание законодателя, адресованное субъектам хозяйствования и другим участникам отношений в сфере хозяйствования, осуществлять свою деятельность в пределах установленного правового хозяйственного порядка, соблюдая требования законодательства (ч. 3 ст. 5 Хозяйственного кодекса Украины). Утверждение общественного хозяйственного порядка в экономической системе Украины провозглашается одной из основных целей Хозяйственного кодекса Украины (преамбула). И хотя «в теории и практике хозяйственного права, так же как в гражданском праве, традиционно не выделяется такой элемент состава, как объект, поскольку здесь нет ярко выраженного законодательного деления санкций в зависимости от области посягательства» [32, с. 251], логично предположить, что объектом любого правонарушения (том числе и преступления) в сфере хозяйствования является правовой хозяйственный порядок. Именно его, в определенных случаях, берет под охрану Уголовный кодекс Украины.

В соответствии с ч. 4 ст. 215 Хозяйственного кодекса Украины такие правонарушения в сфере хозяйствования, как сокрытие банкротства, фиктивное банкротство или умышленное доведение до банкротства, а также неправомерные действия в процедурах неплатежеспособности, связанные с распоряжением имуществом должника, которые причинили существенный ущерб интересам кредиторов и государства, влекут уголовную ответственность виновных лиц в соответствии с законом ${ }^{1}$. Попытки определить родовой объект преступлений в сфере хозяйственной деятельности (раздел VII УК Украины) с иных позиций чреваты весьма серьезными негативными последствиями, вплоть до полной нивелировки объекта таких деяний, в том числе и на законодательном уровне. Так, например, в соответствии со ст. 164.2.12 действующего Налогового кодекса Украины в общий налогооблагаемый доход плательщика налога включаются также деньги либо имущество (нематериальные активы), полученные в виде взятки, похищенные либо найденные в качестве клада, не сданного государству в соответствии с законом, в сумме, определенной обвинительным приговором 
суда независимо от назначенной меры наказания. Предписание взимать налоги с доходов, полученных преступным путем, по сути ставит знак равенства между законными источниками формирования доходов, что соответствует понятию правового хозяйственного порядка, и незаконными способами обогащения. Налогообложение доходов, полученных незаконным путем (хищение, получение неправомерной выгоды, киллерство, проституция, торговля людьми, органами, наркотиками, оружием и др.), полностью стирает грань между социальными (приемлемыми) общественными отношениями, выступающими объектом уголовно-правовой охраны и антисоциальными отношениями, таковыми не являющимися. Что же касается довольно распространенного в последнее время утверждения о том, что такие термины, как «правовое благо», «ценности» и др., являются более конкретными и менее расплывчатыми, чем термин «общественные отношения», то оно, мягко говоря, вызывает возражения. Стремление любой ценой предать забвению «идеологически запятнанные» общественные отношения приводит к тому, что ученые так или иначе пытаются поместить на их место другую социальную категорию, и как результат все сводится к тем же «многострадальным» общественным отношениям.

Так, например, С. С. Яценко определяет общественный порядок как социальную ценность, пребывающую под охраной закона. Однако, раскрывая понятие этой социальной ценности, автор отмечает, что общественный порядок характеризует такое состояние общественных отношений, которое обеспечивает спокойные условия общественно полезной деятельности, отдыха и быта людей, включая внешние условия нормального функционирования предприятий, учреждений и организаций, соблюдение общественной морали, а также принципов пользования материальными благами [33, с. 723]. В. В. Налуцишин, автор одной из монографических работ последних лет издания, полностью разделяя концепцию «объект - социальные ценности», констатирует: «В науке уголовного права под непосредственным объектом хулиганства понимается общественный порядок в части обеспечения спокойных условий общественно полезной деятельности, быта и отдыха людей. Иными словами, совокупность общественных отношений, которые обеспечивают общественное спокойствие, нормальные условия труда, быта и отдыха людей. С этим мы согласиться не можем»[34, с. 57]. Но уже через две страницы В. В. Налуцишин, поддерживая позицию С. Д. Шапченко, делает следующий вывод: «Общественный порядок - это состояние общественных отношений, связанное с соблюдением каждым гражданином условий, определенных правовыми нормами, традиционными моральными и обычными требованиями относительно уважения к власти, правопослушности, соблюдения правил общепринятого поведения в обществе, при котором каждый со своей стороны ведет себя так, как фактически ведут другие. Общественный порядок находится в единстве и взаимообусловленности с правопорядком» [34, с. 61]. 
Не вдаваясь в детали по поводу приведенных определений общественного порядка, заметим - все правильно, одно непонятно: почему в этих определениях претендующие на универсальность «социальные ценности» исчезают, а вместо них появляются «абстрактные», «расплывчатые», «искусственные» и т. д. общественные отношения? Не потому ли, что с позиции общества, как справедливо подчеркивает В. Белоконев, вред не может быть причинен ценностям путем изменения их свойств, поскольку пока они не находятся в системе общественных отношений, они для общества безразличны. Ценности только тогда становятся социально значимыми, когда входят в структуру общественных отношений, а люди становятся их субъектами, когда между людьми возникают конкретные связи по поводу этих ценностей. Поэтому уголовно-правовой охране подлежат не сами ценности, а ценности как элемент общественных отношений [35, с. 14].

В. М. Трубников, отталкиваясь от собственной же точки зрения о «двуобъектности» объекта преступления (основным первичным объектом, которому причиняется вред, выступает социальная оболочка личности, а вторичным - сформированные в данном обществе социальные, общественные отношения, которые и образуют эту оболочку), вдруг делает довольно неожиданный вывод о том, что новым универсальным понятием объекта должны признаваться права и свободы человека и гражданина [36, с. 325]. Свой вывод автор обосновывает ссылками на позицию В. Д. Спасовича, который рассматривал преступление как посягательство на чье-либо право. В этой связи нельзя не согласиться с Я. О. Шаппом, который отмечает: «Основная заповедь морали, касающаяся действительных взаимоотношений людей друг с другом, может быть сформулирована одним предложением: «уважай другого». Заповедь уважения человека человеком уже обуславливает общность с другим человеком, что и делает реальной эту заповедь. Связь с общностью выступает как результат исторического процесса, который объединяет людей в единый поток событий. Речь идет не об обязанности, порождающей связь, а о связи, которая делает возможной саму обязанность» $[37$, c. 89$]$.

Иначе говоря, трактовка прав и свобод человека и гражданина как внесоциальной категории просто абсурдна. Ведь не случайно Конституция Украины признает человека, его жизнь и здоровье, честь и достоинство, неприкосновенность и безопасность не просто наивысшей ценностью, а ценностью социальной. К тому же «универсальность»нового понятия объекта разбивается о первый же раздел Особенной части УК Украины - «Преступления против основ национальной безопасности Украины». Кстати, на это обращал внимание и сам В. Д. Спасович, логическим завершением позиции которого стал его собственный вывод о том, что в конечном итоге преступление причиняет вред «целому правосостоянию, то есть всему быту государственному». Впрочем, на весьма своеобразное цитирование классиков уже обращалось внимание. 
Сама по себе номенклатура прав и свобод человека, как вообщем-то и любое иное нормативное предписание, объективно не может выступать в качестве объекта уголовно-правовой охраны. В противном случае последняя превращается в самоцель. Охране подлежит такой, складывающийся в результате реализации этих предписаний, порядок взаимоотношений между людьми, а также между человеком и государством, при котором все люди свободны и равны в своем достоинстве и правах, права и свободы человека неотчуждаемы и нерушимы и определяют содержание и направленность деятельности государства. М. М. Абрашкович, еще в самом начале прошлого века, справедливо заметил: «Особенно важно понять нравственность не как отвлеченную норму, а как живую силу, которая проникает в борьбу интересов и страстей, чтобы примирить и облагородить ее. Что такое право, как не результат этого примирения, вызванный прикосновением нравственного начала к жизни? Мы представляем себе правовой порядок прежде всего как порядок реальных отношений, как практику жизни, как ту совокупность основных и элементарных требований, без которых самое существованием в обществе было бы немыслимо» [38, с. 618].

Выше уже подчеркивалось, что одна лишь нормативная приоритетность человека, его прав и свобод не более чем декларация, по сути ничего не меняющая с точки зрения складывающейся социальной практики. Специалисты в области конституционного права констатируют, что «права и свободы человека и гражданина еще не стали в Украине реальной ценностью, а каждый четвертый гражданин Украины живет за чертой бедности... Теория и практика безусловно подтверждают решающую роль в системе конституционализма механизменной части защиты прав человека по сравнению с определением прав, сведенных в законы государств и международные стандарты» $[39$, с. 15, 16].

Определяя понятие конституционализма, М.Ф. Орзих приходит к выводу, что это политико-правовая система теории, идеологии и практики, включающая в себя конституционное правосознание, конституционно-нормативные постулаты, конституционные правоотношения, предусматривающие признание и государственную защиту прав и свобод человека и ассоциаций людей, а также субъективные публичные права и свободы (которые могут быть направлены против государственной власти по исковой модели: гражданин А против государства) и конституционную законность [39, с. 24].

Таким образом, права и свободы человека - это не только и не столько их нормативная номенклатура, сколько фактическая реализация и эффективная защита, что, в свою очередь, возможно только в рамках соответствующего социального порядка.

Среди оппонентов концепции объекта как общественных отношений весьма распространенным является тезис о том, что уголовный закон о таком объекте не упоминает.

Так, например, С.Б. Гавриш отмечает следующее: «Законодатель 
никогда не пользовался и не пользуется сейчас при перечислении в соответствующих статьях Уголовных кодексов объектов уголовно-правовой охраны или в каком-нибудь ином смысле термином «общественные отношения». Так, в соответствии с ч. 1 ст. 2 УК РФ перечень этих объектов следующий: «Права и свободы человека и гражданина, собственность, окружающая среда, конституционный строй Российской Федерации, мир и безопасность человечества» $[17$, с. 4].

С ним солидарен и В. П. Емельянов: «Что касается уголовно-правовых норм, то никогда, ни в каком Уголовном кодексе того или иного государства (даже социалистического) общественные отношения не назывались и не называются в качестве объекта уголовно-правовой охраны» [18, с. 64$]$.

На это же обстоятельство обращает внимание и В. М. Трубников: «В общей части Уголовного кодекса Украины (ч. 1 ст. 2) приводится обобщенный перечень объектов уголовно-правовой охраны. К ним относятся права и свободы человека и гражданина, собственность, общественный порядок и общественная безопасность, окружающая среда, конституционный строй Украины» [36, с. 325]. В этом перечне В. М. Трубников сначала особо выделяет права и свободы человека и гражданина, а потом делает вывод о том, что это универсальное понятие объекта преступления. Правда, на каком основании автор абстрагируется от других составляющих им же приведенного перечня и почему «права и свободы человека» наделяются статусом универсального понятия объекта, остается только догадываться.

Прежде чем мы вернемся к аргументу сторонников «новых» подходов к определению объекта преступления, хотелось бы полностью разделить точку зрения Г. П. Новоселова и В. П. Емельянова, которые отмечают следующее: «Понятие объекта преступления нередко увязывается не только с правовыми благами, охраняемыми законом интересами, субъективными правами и т. п., но и с такими общественными отношениями, которые либо что-то регулируют (участие в предпринимательской деятельности, рынок ценных бумаг, внешнеэкономическую деятельность и т. д.), что-то обеспечивают (нормальное функционирование личности, половую неприкосновенность и половую свободу личности ... и т. д.), либо где-то складываются (скажем, в сфере государственного регулирования налогообложения, в сфере потребительского рынка). Подобного рода трактовка «непосредственного» объекта преступления породила конструкции, которые, хотя формально и не вступают в очевидное противоречие с исходным тезисом, явно имеют «налет» искусственности и схоластичности и, самое главное, ничего не дают для практики уголовно-правовых норм» [18, с. 64].

Добавим, что такой подход особенно характерен для уголовно-правовой литературы последних лет издания, когда концепция «объект общественные отношения» уже серьезно расшатана, а взамен, по сути, ничего не создано. 
Так, например, авторы коллективной работы «Окружающая среда как объект уголовно-правовой охраны», поддерживая идею С. Б. Гавриша о необходимости перемещения ст. 268 УК Украины (незаконный ввоз на территорию Украины отходов и вторичного сырья) из раздела IX «Преступления против общественной безопасности»в раздел VIII «Преступления против окружающей среды» [40, с. 127], также приходят к выводу, что объектом этого преступления выступает окружающая среда как определенная ценность (благо) [41, с. 50]. Это благо, по представлению авторов, состоит из отдельных элементов или объектов, на которые посягают те или иные деяния, ответственность за которые предусмотрена разделом VIII Украины [41, с. 51]. Эти элементы определяются следующим образом: нарушение правил экологической безопасности (ст. 236 УК) посягает на общественные отношения по охране окружающей природной среды и экологическую безопасность населения [41, с. 56]; непринятие мер по ликвидации последствий экологического загрязнения (ст. 237 УК) посягает на экологические права граждан и в первую очередь - право экологической безопасности [41, с. 58]; сокрытие или искажение сведений об экологическом состоянии или заболеваемости населения (ст. 238 УК) посягает на конституционное право граждан на экологическую информацию [41, с. 59]; незаконная порубка леса (ст. 246 УК) причиняет вред общественным отношениям по охране леса и лесных насаждений [41, с. 63], а незаконное занятие рыбным, звериными или иным водным добывающим промыслом (ст. 249 УК) - общественным отношениям по охране водных биологических ресурсов [41, с. 73]; общественные отношения по охране окружающей среды - основной непосредственный объект проектирования или эксплуатации сооружений без систем защиты окружающей среды (ст. 253 УК) [41, с. 62].

Авторов, пожалуй, нельзя упрекнуть только в том, что они не упомянули какую-либо из известных концепций объекта преступления.

Здесь действительно есть все: и правовое благо, и социальная ценность, и общественные отношения, и права и свободы человека, и сам человек. Создается впечатление, что для упомянутых авторов этот вопрос вообще не имеет принципиального значения. К сожалению, подобный подход характерен и для некоторых общетеоретических источников. Так, например, авторы учебного курса «Общетеоретическая юриспруденция» под редакцией Ю. Н. Оборотова констатируют следующее: «Объект правонарушения - общественные отношения, социальные блага, ценности, права и свободы личности, интересы государства, природная среда, на которые посягает правонарушитель. Выделяют общий и конкретный объект правонарушения. Общий объект - это совокупность всех общественных отношений и социальных ценностей, охраняемых правом. Конкретный объект - это определенные для каждого случая материальные и нематериальные блага и ценности (природная среда, собственность, жизнь, честь, достоинство), а также отношения, возникающие по поводу обладания ими» [31, с. 287]. 
В. Н. Киричко и А. И. Перепелица, авторы весьма солидного труда «Преступления в сфере хозяйственной деятельности по Уголовному кодексу Украины и в судебной практике», определяя понятие объекта легализации (отмывания) доходов, полученных преступным путем (ст. 209 УК Украины), в качестве такового называют общественные отношения в сфере занятия хозяйственной деятельностью и борьбы с легализацией (отмыванием) доходов, полученных преступным путем [42, с. 116].

При всем уважении к авторам, представить себе объект этого преступления как «общественные отношения в сфере борьбы...» (то есть ведется какая-то борьба с легализацией доходов и в рамках этой борьбы есть сфера, охраняемая уголовным законом) довольно сложно. Объект незаконного изготовления, хранения, сбыта либо транспортировки с целью сбыта подакцизных товаров (ст. 204 УК).В.Н.Киричко и А. И. Перепелица трактуют следующим образом: это «общественные отношения в сфере хозяйственной деятельности с подакцизными товарами, которые обеспечивают: по ч. 1 и ч. 2 - соблюдение установленного порядка производства и оборота подакцизных товаров и обязательную уплату акцизного сбора; по ч. 3 - охрану жизни и здоровья потребителей подакцизных товаров и их законные интересы» [42, с. 78]. Определение основного непосредственного объекта деяния, предусмотренного ч. 3 ст. 204 УК, как жизни и здоровья человека абсолютно необоснованно, поскольку в целом речь идет о преступлении в сфере хозяйственной деятельности. Изготовление подакцизных товаров из недоброкачественного сырья основной направленности этого преступления не меняет. Жизнь и здоровье людей ч. 3 ст. 204 УК охраняет в качестве дополнительного непосредственного объекта, что авторами попросту игнорируется.

Безусловно, общественные отношения ничего не регулируют (они сами нуждаются в регламентации), ничего не обеспечивают (наоборот, обеспечение их нормального функционирования достигается за счет правовой и неправовой регламентации) и не могут где-то складываться (общественные отношения неотъемлемы от человеческой деятельности, создаются в процессе этой деятельности, а потому не могут ни существовать, ни изменяться независимо от нее. В свою очередь, деятельность человека неминуемо включается в систему общественных отношений. Общественные отношения и человеческая деятельность сами по себе (автономно) существовать не могут). Подход к объекту преступления как к общественным отношениям, которые что-то регулируют, обеспечивают или где-то складываются, действительно отрывает это понятие от реальной действительности и создает иллюзию того, что существует еще что-то, что они регулируют, обеспечивают или ради чего складываются. Именно эта искусственно созданная двойственность и породила самые различные, порой просто абсурдные, трактовки непосредственных объектов тех или иных преступных деяний. 
Теперь вернемся к приведенному выше исходному тезису оппонентов теории объекта преступления как общественных отношений. Действительно, действующее уголовное законодательство Украины, как и законодательство других постсоветских республик, термином «общественные отношения» не оперирует. Однако, что представляют из себя упомянутые в ч. 1 ст. 1 УК Украины права и свободы человека и гражданина, собственность, общественный порядок и общественная безопасность, окружающая среда, конституционный строй, мир и безопасность человечества? Это не что иное, как урегулированные иными отраслями права, нравственными предписаниями и обычаями различные сферы социальных отношений.

Выше уже обращалось внимание на то, что права и свободы человека реализуются посредством определения прав и обязанностей иных лиц, общества, государства по их обеспечению. Қаждый человек имеет право на свободное развитие своей личности, если при этом не нарушаются права и свободы других людей, и имеет обязанности перед обществом, в котором обеспечивается свободное и всестороннее развитие его личности, - гласит ст. 23 Конституции Украины. Поэтому посягательство на права и свободы человека и гражданина является посягательством на одноименные общественные отношения. Так, например, ст. 27 Конституции Украины провозглашает право на жизнь неотъемлемым правом каждого человека, параллельно возлагая на государство обязанности по его защите. Указание в ч. 1 ст. 115 УК Украины на причинение смерти другому человеку свидетельствует о том, что убийца вступает во взаимодействие не с белковым телом (поскольку жизнь есть способ существования белковых тел) или «формой биологического существования» (вспомним позицию Н. С. Таганцева и Л. С. Белогриц-Котляревского относительно критериев разграничения убийства от иных посягательств), а в отношения между людьми по поводу неприкосновенности человеческой жизни. Следовательно, уголовный закон охраняет не жизнь конкретного человека (иначе к уголовной ответственности необходимо было бы привлекать любые источники угроз жизни человека - от болезней и эпидемий до несчастных случаев и стихийных бедствий и нельзя было бы обосновать ненаказуемость самоубийства, лишение жизни другого человека в военное время или боевой обстановке, в состоянии необходимой обороны, при правомерном применении специальными субъектами оружия при задержании преступника, при приведении в исполнение приговоров к смертной казни), а отношения между людьми, основанные на признании неприкосновенности жизни.

Аналогичным образом обстоит дело и с другим, упомянутым в ч. 1 ст. 1 УК Украины, объектом, - собственностью «Собственность характеризуется наличием такой власти лица над вещью, которое признано обществом и регламентировано социальными нормами. Собственник распоряжается вещью своей властью и в своих интересах. Для него вещь - своя, для несобственников, соответственно - чужая. 
Поскольку власть лица (собственника) над вещью невозможна без того, чтобы другие лица (которые не являются собственниками вещи) относились к ней как к чужой, собственность означает отношения между людьми по поводу вещей. На одном полюсе этого отношения - собственник, который относится к вещи как к своей, на другом - несобственники, то есть все другие лица, которые обязаны относиться к ней как к чужой. Это означает, что они обязаны воздерживаться от любых посягательств на чужую вещь, а следовательно, и на волю собственника иметь эту вещь.

Таким образом, собственность - это общественное отношение, которое характеризуется двумя основными признаками: 1) оно возникает по поводу вещей (имущества); 2) оно имеет волевое содержание. Из первого признака следует, что собственность - это всегда имущественное отношение. Наличие второго признака предопределяет необходимость учета значения такой категории, как «воля собственника», установление пределов волеизъявления собственника» - констатируют авторы научно-практического комментария Гражданского кодекса Украины под редакцией Е. О. Харитонова [43, с. 342-343]. Как справедливо отмечает А. И. Бойцов, «указание закона на изъятие и обращение в пользу виновного или других лиц чужого имущества недвусмысленно говорит о том, что, совершая хищение, виновный вступает во взаимодействие не с вещью, а с ее собственником и нарушает не отношение последнего к вещи, а существующие между людьми отношения собственности, покоящиеся на различии своего и чужого. Уголовный закон охраняет не вещи сами по себе, а отношения между людьми, основанные на признании собственности. Именно в указании на понимаемый таким образом объект находит свое отражение социально-разрушительная сущность приведенных в УК деяний [26, с. 21-22]. Взгляд на общественные отношения собственности в качестве объекта преступления позволяет понять, почему опасность каждого из посягательств этой группы не может измеряться только размером причиненного индивиду материального ущерба, почему наказуемо покушение на хищение, вовсе не влекущее материального ущерба, а также ответить на ряд других вопросов, решение которых «непосредственно зависит от того, что понимается под объектом преступления, каков механизм воздействия деяния человека на объект преступления и в чем заключается ущерб, причиненный объекту» [26, с. 22].

Вытекающий отсюда вывод, в соответствии с которым объектом преступлений против собственности выступают отношения собственности, а предметом - имущество, является абсолютно логичным и вполне обоснованным. Подвергнуть его конструктивной критике довольно сложно, если только не представить преступления против собственности в качестве уголовно-правовой фикции. Так, например, В. В. Векленко предлагает заменить нынешнее наименование главы 21 УК РФ, как не соответствующее ее действительному содержанию, на «Преступле- 
ния против чужого имущества»и тем самым более точно определить объект и предмет рассматриваемых преступлений», поскольку «зафиксированные в ней составы в большей части обращены к охране отношений по поводу имущества» [44, с. 16].

Эту же позицию отстаивает и В. П. Емельянов: «В первую очередь неточным является само название главы «Преступления против собственности». Эта глава включает в себя лишь незначительную часть преступлений, затрагивающих интересы собственников, а именно, имущественные преступления, и то в основном в отношении движимого имущества. За рамками этой главы остаются преступления против интеллектуальной собственности, собственности на землю и многие другие, поэтому более точным для данной главы было бы название «Имущественные преступления» [18, с. 68].

Такой подход, по мнению В. П. Емельянова, «представляется совершенно правильным, поскольку вред в данных случаях причиняется действительно имуществу, а не праву собственности на это имущество, ибо в результате похищения имущества собственник не утрачивает права собственности на него и может в любой момент истребовать свое имущество от любого незаконного владельца, а виновное лицо никогда не сможет обрести права собственности на находящееся в незаконном пользовании имущество, т. к. в соответствии с гражданским законодательством право собственности возникает на законных основаниях» [18, с. 69].

Свой вывод В. П. Емельянов аргументирует ссылками на положения УК РСФСР (1922 и 1926 г.г.) и других республик, где соответствующие главы назывались «Имущественные преступления» и «не возникало вопроса о том, что является объектом, а что - предметом, все было едино», уголовно-правовую литературу 30-50-х годов ХХ века, где тоже ставился знак равенства между собственностью и имуществом, а также ссылками на положения зарубежного уголовного законодательства, где речь идет о «Преступных деяниях против имущества» (УК Швейцарии), «Преступлениях против имущества» (УК КНР), «О краже, разбое и других преступлениях, связанных с похищением имущества» (УК Швеции) и др. [18, с. 68-69].

Как уже отмечалось, положения зарубежного уголовного законодательства в этой части вряд ли могут претендовать на роль универсальных стандартов ${ }^{2}$. Еще раз подчеркнем - учение об объекте преступления в западной уголовно-правовой доктрине особого развития не получило.

Так, английская доктрина уголовного права в ее классическом варианте рассматривает преступление в целом как единство двух элементов: actus reus (запрещенного поведения в самом широком, общем смысле слова) и mens rea (сопутствующего такому поведению психического настроя). Согласно представлениям французских юристов преступление - это действие или бездействие, предусмотренное и наказуемое 
уголовным законом, вменяемое в вину его исполнителю и не оправданное осуществлением какого-либо права. По мнению Ж. Левассера, А. Шавана и Ж. Монтрея, преступное деяние включает четыре признака: материальный, уголовной противоправности (или «легальный»), моральный (психологический) и признак «неоправданности».

Последний означает, что отсутствуют причины для оправдания совершенного деяния: лицо не действовало в условиях необходимой обороны или крайней необходимости, не исполняло приказ вышестоящего начальника, не действовало под принуждением или в результате ошибки в праве [45, с. 153]. В более позднем труде Ф. Конта и П. Мэстра дю Шамбона к основным признакам преступного деяния отнесены два: материальный и моральный. При этом авторы полагают, что названные признаки - это элементы, совокупность которых обусловливает наличие состава преступного деяния. Что касается «легального» элемента, то его следует считать «компонентом», а не «составляющим» элементом преступного деяния [45, c. 153]. «Таким образом, - как отмечают Г. А. Есаков, Н. Е. Крылова и А. В. Серебренникова, - в теории французского уголовного права не выработано не только какого-либо единого понятия преступного деяния, но и единого мнения по поводу того, что следует считать его основными признаками и структурными элементами» $[45$, с. 153$]$.

В немецкой уголовно-правовой доктрине преступным деянием признается противоправное, виновное, соответствующее признакам «состава закона» деяние, находящееся под угрозой наказания [45, с. 189]. Специалисты отмечают, что в современном немецком уголовном праве понятие противоправности существенно расширилось. Она не сводится к противоречию только уголовному закону, а понимается в более широком смысле слова: противоречие деяния правопорядку в целом, т. е. соответствующее деяние содержит признаки «состава закона» преступного деяния или нарушения общественного порядка. Такое деяние только тогда не является противоправным, когда у лица отсутствует понимание того, что оно действует противоправно, если оно не могло избежать этой ошибки (\$17 УК). Поэтому ошибка в запрете (т. е. ошибка лица относительно того, что оно действует противоправно), как правило, влечет за собой признание невиновности лица. Если же лицо заблуждается в фактических обстоятельствах дела (т. е. его заблуждение относится к определенным признакам конкретного «состава закона»), то считается, что такая ошибка исключает совершение умышленного деяния и лицо может быть наказано только за совершение деяния по неосторожности (абз. 1 \$ 16 УК) [44, с. 190]. «Соответствие составу закона» понимается как выполнение конкретным деянием законодательно определенных признаков состава закона, т. е. признаков, определенных в соответствующей норме. О соответствии преступного деяния составу закона или о выполнении состава закона речь может идти только тогда, когда его признаки соответствуют всем признакам состава закона. В бо- 
лее узком смысле слова «состав закона» понимаются как законодательное определение объективных и субъективных предпосылок поведения, находящегося под угрозой наказания, необходимых для признания его преступным деянием. Составы закона детально регламентируются в Особенной части УК.

Существенной особенностью германского уголовного права является то, что вина не рассматривается как элемент состава закона [45, с. 19].

Как видим, в западной уголовно-правовой доктрине объект преступления не фигурирует в качестве необходимого элемента преступного деяния (состава деяния). Поэтому его установление при привлечении лица к уголовной ответственности не требуется. Отсюда и довольно произвольное построение системы Особенной части УК. Отечественная же уголовно-правовая доктрина в этом вопросе стоит на принципиально иных позициях, рассматривая объект преступления в качестве обязательного элемента состава и провозглашая основанием уголовной ответственности совершение лицом общественно опасного деяния, содержащего состав преступления, предусмотренный УК (ч. 1 ст. 2 УК Украины).

Такое положение вещей позволяет усомниться в состоятельности позиции, касающейся необходимости переименования раздела VI УK Украины «Преступления против собственности» в «Имущественные преступления», аргументированной ссылками на зарубежное уголовное законодательство, как, впрочем, и ссылками на собственный исторический опыт, поскольку за основу берется период, когда целостное учение об объекте преступления еще не сложилось.

Статья 177 ГК Украины вещи, имущество и имущественные права не отождествляет, рассматривая их в качестве самостоятельных объектов гражданских прав. Вещью является предмет материального мира, относительно которого могут возникать гражданские права и обязанности (ст. 179 ГК), а имуществом как особым объектом считаются отдельная вещь, совокупность вещей, а также имущественные права и обязанности (ст. 190 ГК). Вполне очевидно, что ни «имущественные права», ни «имущественные права и обязанности»не могут быть отнесены к «предметам материального мира», как на то ориентирует определение вещи, содержащееся в ст. 179 ГК.

Выход из положения цивилисты усматривают в делении вещей на телесные (имеющие материальный субстрат) и бестелесные (не имеющие материального субстрата) [46, с. 202].

Что же касается права собственности, то таковым в соответствии с ч. 1 ст. 316 ГК Украины является право лица на вещь (имущество) как телесный объект. Юридическая принадлежность вещи определенному лицу означает, что все другие лица обязаны признавать эту принадлежность и не нарушать ее. Поэтому вещно-правовую защиту еще называют абсолютной, подчеркивая этим, что собственник вещного права может получить защиту от нарушений со стороны «всех и каждого» 
[46, с. 312]. Имущественные права и обязанности (бестелесные объекты) гражданское право относит к сфере обязательственных отношений (книга V ГК Украины).

Если права на вещи опосредуют статику общественных отношений (состояние принадлежности вещей) в сфере гражданского оборота, то обязательства прежде всего обеспечивают его динамику, регулируя обязанности по передаче вещей от одного лица другому, выполнению действий, предоставлению услуг.

Обязательства являются одним из видов гражданских правоотношений и обладают всеми признаками последних. Вместе с тем они имеют и специфические черты, которые позволяют выделить их из общей совокупности гражданских правоотношений и, в частности, отделить от вещных отношений:

1) сторонами обязательства являются конкретно определенные лица: кредитор - лицо, которому принадлежит право требования, и должник (дебитор) - лицо, которое несет обязанность, соответствующую праву требования кредитора. Этим обязательства (относительные правоотношения) отличаются от абсолютных правоотношений (правоотношений собственности и т. п.), в которых управомоченному лицу противопоставлен не конкретный круг обязанных лиц, а «все и каждый»;

2) объектами обязательственных правоотношений могут быть действия, связанные с передачей имущества, выполнением работ и т. п., или воздержание от совершения действий, в то время как объектами вещных правоотношений являются вещи;

3) осуществление субъективного права кредитора в обязательственных правоотношениях возможно только в случае совершения должником действий, которые составляют его обязанность, тогда как в вещных правоотношениях уполномоченное лицо может осуществлять свои субъективные права самостоятельно, не обращаясь за помощью к другим лицам;

4) обязательства опосредуют динамику гражданского оборота. Вещные права - это его статика.

С учетом этих признаков обязательства в цивилистической литературе чаще всего определяют как гражданские правоотношения (или «закрепленные гражданским законом общественные отношения»), связанные с перемещением имущественных и других результатов труда, в результате которых одно лицо (кредитор) имеет право требовать от другого лица (должника) совершения или воздержания от совершения определенных действий [46, с. 442].

Практически так же выглядит и легальное определение обязательства, содержащееся в ст. 509 ГК, согласно которому обязательством является правоотношение, в котором одна сторона (должник) обязана совершить в интересах второй стороны (кредитора) определенное действие (передать имущество, выполнить работу, предоставить услугу, уплатить деньги и т. п.) или воздержаться от определенного действия, 
а кредитор имеет право требовать от должника выполнения его обязанности.

Следует отметить и то обстоятельство, что указание законодателя на односторонний характер обязательства (одна сторона имеет права, а другая - обязанности), в гражданско-правовой литературе признается некорректным, поскольку такая простая правовая связь в практике встречается достаточно редко (в договорах простого дарения, безвозмездной ссуды, займа, пожизненного содержания, а также в обязательствах о возмещении вреда). Чаще всего речь идет о взаимосвязи прав и обязанностей сторон обязательства. Например, в договоре купли-продажи продавец обязан передать покупателю определенную вещь, и в этом отношении он является должником. Также он имеет право требовать от покупателя уплаты покупной цены, в этом отношении является кредитором. Покупатель, в свою очередь, выступает как кредитор, требуя передачи вещи, и как должник - выполняя обязанность заплатить за покупку.

Выяснение того, действует ли сторона в конкретной ситуации как должник или как кредитор, имеет большое значение для правильного применения других норм (например, тех, которые устанавливают последствия просрочки должника или просрочки кредитора). Следовательно, такое обстоятельство должно быть учтено при определении понятия этой категории. С учетом этого гражданско-правовое обязательство определяется как гражданское правоотношение, участники которого имеют права и обязанности, направленные на опосредование динамики гражданских отношений; передачу имущества, выполнение работы, предоставление услуги, уплату денег и т. п. [46, с. 443]. В свою очередь, любое правоотношение есть не что иное, как «специфический вид общественных отношений» [31, с. 143].

Таким образом, гражданское право четко разграничивает абсолютные правоотношения (собственность) и правоотношения относительные (обязательства). ГК Украины посвящает этим вопросы две самостоятельные книги: книгу третью - праву собственности и другим вещным правам, книгу пятую - обязательственному праву. Именно с этих позиций подходит к охране обозначенных выше «специфических видов общественных отношений» и уголовное законодательство, предусматривая охрану собственности в VI разделе, а хозяйственной деятельности в VII разделе УК Украины. Отказ от понятия «преступления против собственности»и замена его понятием «имущественные преступления» неизбежно приведут к полному смешению этих понятий и невозможности разграничения преступлений против собственности и преступлений в сфере хозяйственной деятельности. То обстоятельство, что УК Украины в соответствующих статьях оперирует понятием «чужое имущество», а не «чужая собственность», с нашей точки зрения, абсолютно обоснованно, поскольку завладение отношением по природе своей невозможно. К тому же имущество при краже, грабеже, разбое, мошен- 
ничестве, вымогательстве как раз и не страдает. Если предположить, что имущество, а не собственность является объектом этих преступлений, придется признать одно - они безобъектны, поскольку деяний, ничему не причиняющих вреда, объективно не существует. Предвидя такую ситуацию, В. П. Емельянов отмечает: «Нередко в качестве контраргумента используется тезис, что при похищении имущества похищенной вещи никакого вреда не причиняется, а значит, имущество не является объектом преступления. Однако этот тезис тоже есть не что иное, как результат смешения понятий. Действительно, конкретной вещи, которая похищена, никакого ущерба не причиняется и причинено быть не может, ибо не для того данная вещь похищается, чтобы причинить ей вред, а для того, чтобы извлечь из этого какую-то пользу. Ущерб причиняется имуществу собственника как совокупности имущественных благ, как некоей имущественной массе, наличному имущественному фонду, который реально уменьшается за счет похищения той или иной вещи. Именно в этом смысле имущество выступает в качестве объекта (предмета) преступления» [18, с. 69].

Следует согласиться с В.П. Емельяновым, что имущество в этом смысле выступает в качестве объекта, только в этом смысле оно и есть не что иное, как собственность. Оприходование (попадание в фонды активы) имущественной массы и означает ее присвоение и установление над ней права собственности. K выводу об отождествлении имущества и собственности в конце концов приходит и В.В. Векленко.

При этом, вначале не ставя знак равенства между собственностью и имуществом, «поскольку имущество - значительно более широкое понятие», становящееся собственностью лишь «при установлении над ним законного права владения, пользования и распоряжения», автор ставит под сомнение мысль о том, что в гл. 21 УК РФ собственность трактуется как объект», поскольку «в большинстве статей данной главы законодатель применительно к предмету преступлений использует понятие «имущество», что не вызывает у В.В. Векленко «никаких претензий, так как собственность граждан, юридических лиц, государственная и муниципальная в ст. ст. 212-215 ГК РФ определяется посредством указания на имущество, а в ряде случаев и прямо отождествляется с ним» $[44$, с. 16$]$.

Таким образом, попытки подменить понятие собственности понятием имущества и представить последнее в качестве объекта преступлений, предусмотренных разделом VI УК Украины, с нашей точки зрения, абсолютно несостоятельны.

Конституционный строй Украины, при всей сложности и многозначительности этого понятия, в теории конституционного права определяется как реально существующий общественный и государственный строй. «Его основу составляют те объективно существующие общественные отношения, которые определяют наиболее существенные экономические, политические, социальные и иные характеристики общества. Таким 
образом, по своему содержанию, конституционный строй включает в себя ряд составляющих. Основными среди них являются: основы социальных отношений, основы политических отношений, основы экономических отношений, основы духовной жизни, основы правового статуса личности» $[47$, с. 78$]$. «Конституционный строй, - справедливо замечает А. А. Майданник, - это официальный общественный и государственный строй и официальная система иных общественных отношений, предусмотренных и гарантированных Конституцией и законами, принятыми на ее основе и в соответствии с ней» [47, с. 79].

Упомянутые в ч. 1 ст. 1 УК Украины общественный порядок и общественная безопасность говорят сами за себя. Что же касается мира и безопасности человечества, относительно нового для уголовного законодательства Украины объекта уголовно-правовой охраны, то на характеристике этого понятия следует остановиться подробнее.

Международно-правовые акты понятие «мир и безопасность человечества» не раскрывают, констатируя лишь, что посягающие на них деяния относятся к самым тяжким (преамбула к Конвенции о неприменяемости срока давности к военным преступлениям и преступлениям против человечества от 26 ноября 1968 г.). В литературе это понятие трактуется неоднозначно. Так, по мнению Ю. В. Николаевой, объектом преступлений против мира и безопасности человечества являются общественные отношения по обеспечению всеобщего мира и всеобщей безопасности [48, с. 5]. Выше уже обращалось внимание на необоснованность такого подхода к определению объекта преступления, поскольку общественные отношения ничего не обеспечивают (регламентируют) и где-то там не складываются.

Н. Ф. Кузнецова называет непосредственными объектами ряда преступлений против мира и безопасности человечества «основы мира, т. е. мирного взаимодействия государств при решении любых проблем, исключающего какое-либо насилие», «международные правоотношения в сфере соблюдения правил ведения войны или разрешения вооруженных конфликтов», «основы человечества и человечности, т. е. международного обеспечения безопасности национальных, этнических, расовых, религиозных групп» [49, с. 353, 366, 383].

Г.В. Матусевич отмечает, что преступления против мира и безопасности человечества «способны причинить невосполнимый ущерб самим основам существования жизни на земле, так как объектом их посягательства являются не отдельные общественные отношения в той или иной сфере жизни и деятельности человека, общества, государства, а сама жизнь на земле, существование человечества или значительной его части» [50, с. 485].

А. Г. Кибальник и И. Г. Соломоненко, посвятившие характеристике преступлений против мира и безопасности человечества специальное монографическое исследование, вслед за А. В. Наумовым приходят к выводу, что теория объекта как общественного отношения «не срабаты- 
вает» в целом ряде случаев. С их точки зрения, в уголовно-правой теории наметился своеобразный поворот к пониманию объекта правовой охраны не только как общественного отношения в узком смысле этого слова, но и как реального блага, интереса [51, с. 19].

«Такое понимание объекта преступления, - отмечают авторы, - в большей мере соответствует новой иерархии объектов уголовно-правой охраны, переоценка которых произошла в УК РФ 1996 г. Как известно, буква Уголовного закона гласит, что под охрану взяты «права и свободы человека и гражданина ... мир и безопасность человечества» (ч. 1 ст. 2 УК РФ) как самостоятельные ценности, без обязательной их реализации в общественных отношениях как таковых, т. е. в отношениях нескольких (минимум - двух) субъектов уголовного правоотношения [51, с. 19].

По всей вероятности, А. Г. Кибальник и И. Г. Соломоненко не разграничивают общественные отношения как объект уголовно-правовой охраны и общественные отношения, составляющие предмет уголовно-правового регулирования. Непонятно к тому же, каким образом охраняемые законом ценности могут быть реализованы в уголовном правоотношении. «Непосредственным объектом преступления должен считаться тот юридический интерес, которому изначально причиняется вред конкретным преступлением либо создается угроза причинения такого вреда [51, c. 19].

Руководствуясь этим тезисом, А. Г. Кибальник и И. Г. Соломоненко приводят такие дефиниции. «Безопасность человечества как охраняемый уголовным правом интерес (объект) представляет собой состояние защищенности человечества в целом либо демографических групп от угроз их физическому существованию, исходящих от субъектов уголовного права» [51, с. 20].

«Непосредственным объектом преступлений против мира признаются охраняемые общепризнанными принципами международного права и международным правом интересы соблюдения всеобщего мира и правил мирного урегулирования межгосударственных споров» [51, с. 21].

«Основным непосредственным объектом военных преступлений признаются охраняемые общепризнанными принципами международного права и международным гуманитарным правом интересы, соблюдение правил ведения вооруженных конфликтов международного и немеждународного характера» [51, с. 24].

«На основе приведенных рассуждений, полагаем, - продолжают упомянутые авторы, - что под интересами мира и безопасности человечества как родовым объектом национальной уголовно-правой охраны надо понимать:

- интересы обеспечения мирного сосуществования государств и мирного разрешения межгосударственных споров;

- интересы обеспечения физического существования неопределенного круга лиц (человечества в целом либо демографических групп) от любых угроз, источником которых является человеческий фактор; 
- интересы соблюдения правил ведения вооруженных конфликтов международного и немеждународного характера» [51, с. 24].

Итак, попытка вырвать мир и безопасность человечества из «отношенческой» плоскости и представить их в виде самостоятельной ценности, витающей в неком асоциальном вакууме, явно не удалась, поскольку обеспечение равновесия между интересами различных государств, равно как и состояние защищенности человечества в целом либо отдельных демографических групп, возможно только в условиях определенного социального порядка.

Иначе говоря, мир и безопасность человечества - это состояние упорядоченности социальными нормами (нормами права, морали, нормами-обычаями) одноименных общественных отношений. Антиподом порядка является хаос и беспорядок, произвол и беззаконие. Ведь не случайно сами же авторы приходят к выводу, что «юридическое понимание мира и безопасности человечества можно определить исходя из анализа противоположных состояний человеческого общества, что мир - это состояние, характеризующиеся отсутствием войны» и т.д. [51, с. 19]. Характеризуя военные преступления, А. Г. Кибальник и И. Г. Соломоненко в конце концов констатируют, что «они посягают на установленный в международном гуманитарном праве порядок ведения вооруженных конфликтов международного и немеждународного характера. Данный регламентированный порядок ведения военных действий в вооруженных конфликтах является составной частью интересов мира и безопасности человечества» [51, с. 23].

А далее следует вполне закономерный, с нашей точки зрения, вывод: «Предупреждение преступлений против мира и безопасности человечества должно расцениваться в контексте поддержания мирового правопорядка (как совокупности всех интересов, взятых под защиту всеми отраслями права) в целом» [51, с. 27].

Мировой правопорядок рассматривается в качестве объекта тягчайших международных преступлений (геноцид, подготовка и ведение агрессивной войны, нарушение законов и обычаев войны и т. п.) и в общей теории права [31, с. 286].

Таким образом, перечисленные в ч. 1 ст. 1 УК Украины (ч. 1 ст. 2 УК РФ) объекты уголовно-правовой охраны есть не что иное, как «специфические виды общественных отношений», находящиеся в состоянии социальной (посредством норм морали, традиций, обычаев) и правовой (посредством норм права) упорядоченности.

Выше уже отмечалось, что уголовно-правовая доктрина досоветского периода, подходя к определению объекта преступления с принципиально верных методологических позиций, все же не смогла преодолеть нормативных рамок («сковывающих рамок права»), сводя это понятие к «норме права», «правосостоянию»и т. д. Использование категории общественных отношений, упорядоченных с помощью как правовых, так и неправовых регуляторов, эту проблему, как представляется, полностью 
разрешило. В то же время нельзя не отметить то обстоятельство, что Конституционный Суд Украины в своем решении от 2 ноября 2004 г. (дело о назначении судом более мягкого наказания), определяя принцип верховенства права, указывает, что «верховенство права - это господство права в обществе. Одним из проявлений этого принципа является то, что право не ограничивается только законодательством как одной из его форм, а включает и иные социальные регуляторы, в частности, нормы морали, традиции, обычаи и т.д., легитимированные обществом и обусловленные исторически достигнутым культурным уровнем общества. Все эти элементы права объединяются качеством, соответствующим идеологии справедливости, идее права, которая в значительной степени нашла отражение в Конституции Украины» [52, с. 40]. Понятно, что в своем решении Конституционный Суд Украины не преследовал цели отождествить право и иные социальные регуляторы, а лишь предпринял попытку разграничить право и закон. Не случайно здесь же отмечается, что «такое понимание права не дает оснований для его отождествления с законом, который иногда может быть и несправедливым, в том числе ограничивающим свободу и равенство личности» [52, c. 40]. Поддерживая в целом идею Конституционного Суда Украины о необходимости разграничения права и закона, используемую им аргументацию вряд ли можно считать удачной, поскольку в своем логическом завершении такой подход приводит к отождествлению общественного порядка как состояния упорядоченности социальными нормами (нормами права, морали, обычаями) системы общественных отношений и правопорядка - стабильного состояния правовой упорядоченности системы общественных отношений, складывающегося в условиях реализации правовых норм, принципов и требований законности, - что абсолютно необоснованно. Эти понятия четко разграничиваются как в общей теории права [53, с. 718-719], так и в теории конституционного права [54, с. 64]. Да и Конституция Украины устанавливает в ч. 1 ст. 19 положение о том, что правовой порядок в Украине основывается на принципах, в соответствии с которыми никто не может быть принужден делать то, что не предусмотрено законодательством. «В таком ракурсе, - отмечает В. Е. Телипко, - правовой порядок представляет собой состояние упорядоченности, урегулированности, организованности общественных отношений, которое формируется, существует и функционирует вследствие реализации норм права в соответствии с принципом законности» [54, с. 64]. Отождествление общественного порядка (в широком значении) и правопорядка, складывающегося только на основе правовых норм и вследствие этого охраняемого специальными государственно-правовыми средствами, так или иначе вернет уголовно-правовую доктрину при определении понятия объекта преступления в «сковывающие рамки права», лишив многие деяния, не связанные с посягательством на «норму права» (например, преступления против половой свободы, поскольку сфера интимных отношений не урегулирована нормативными предписаниями) своего объекта. 


\section{Пр и ме ч а н и я}

1. Законом Украины «О внесении изменений в некоторые законодательные акты Украины относительно гумманизации ответственности за правонарушения в сфере хозяйственной деятельности» от 15 ноября 2011 г. такие преступления, как фиктивное банкротство (ст. 218 УК Украины) и незаконные действия при банкротстве (ст. 221 УК), были декриминализированы и переведены в разряд административных правонарушений (ст. $166^{16}$ и $166^{17}$ Кодекса Украины об административных правонарушениях). Декриминализировано также и сокрытие устойчивой финансовой несостоятельности (ст. 220 УК), Однако в интересующем нас аспекте эта новелла ровным счетом ничего не меняет.

2. Так, например, раздел VI УК Австрии «Преступные деяния против чужого имущества» не только полностью отождествляет вещи и имущество, но и объявляет наказуемыми по статьям этого раздела такие деяния, как повреждение данных (\$126 a), нарушение работоспособности компьютерной системы (\$ 126 b), посягательство на чужие права охоты и рыболовства (\$ 137$)$, применение силы браконьером (\$ 140$)$ и др. Такая система, с нашей точки зрения, не может избежать упрека в полном смешении понятий. Более того, трактовка вещи (имущества) как объекта посягательств этой группы приводит к конструированию весьма специфических положений, вызывающих некоторые недоумения. Часть 2 \$ 144 УК Австрии (вымогательство) гласит: «Деяние не является противоправным, если применение насилия или угроза не противоречат добрым нравам как средство для достижения поставленной цели». Таким образом, применение насилия может быть оправдано целью возвращения долга или своего имущества из чужого владения. Не трудно себе представить, как заимствование подобных положений (в условиях украинской реальности, когда действия государственных институтов зачастую неэффективны) скажется на активизации «добрых нравов» лиц, специализирующихся на «выбивании» чужих долгов.

\section{Лите р а т у р а}

1. Кримінальне право України. Загальна частина: підручник / В. I. Борисов, В. Я. Тац̧ій, B. I. Тютюгін [та ін.] ; за ред. В.Я. Тація, В. І̇. Борисова, В. І̇. Тютюгіна. - 5-те вид., переробл. і допов. - Х. : Право, 2015. - 528 с.

2. Гавриш С. Б. Уголовно-правовая охрана природной среды Украины. Проблемы теории и развития законодательства / С. Б. Гавриш. - Х. : Основа, 1994. - 640 с.

3. Трубников В. М. Новый взгляд на объект преступления / В. М. Трубников // Право і безпека. - 2002. - № 1. - С. 84-87.

4. Туляков В. А. Виктемологические проблемы применения нового Уголовного кодекса / В. А. Туляков // Новий Кримінальний кодекс України: питання застосування і вивчення: матеріали Міжнар. наук.-практ. конф. [Харків], 25-26 жовт. 2001 р. / редкол.: В. В. Сташиса [та ін.]. - К.; Х., 2002. - С. 234-237.

5. Емельянов В. П. Понятие объекта преступлений в уголовно-правовой науке / В. П. Емельянов // Право і безпека. - 2002. - № 4. - С. 7-11.

6. Наумов А. В. Уголовное право. Общая часть: курс лекций / A. В. Наумов. - М. : HOPMA, 1996. - 547 c.

7. Уголовное право: учеб. для вузов. Т. 1. Общая часть / под ред. А. Н. Игнатова, Ю. А. Красикова. - М., 1998. - 484 с.

8. Расторопов С. Понятие объекта преступления: история, состояние, перспектива / C. Расторопов // Уголовное право. - 2002. - № 1. - С. 37-40.

9. Новоселов Г. П. Учение об объекте преступления: методологические аспекты / Г. П. Новоселов. - М. : НОРМА, 2001. - 160 с.

10. Фесенко $Є$. В. Злочини проти здоров'я населення та система заходів з його охорони: монографія / Є. В. Фесенко. - К. : Атіка, 2004. - 280 с. 
11. Андрушко П. П. Злочини проти виборчих прав громадян та їх права брати участь у референдумі: кримінально-правова характеристика / П. П. Андрушко. - K. : КНТ, 2007. - 328 с.

12. Андрушко П. П. Злочини у сфері службової діяльності: кримінально-правова характеристика : навч. посіб. / П. П. Андрушко, А. А. Стрижевська. - К. : Юрисконсульт, 2006. - 342 с.

13. Дзюба В. Т. Потерпілий від злочину в сфері господарської діяльності: його види та юридичні ознаки / В. Т. Дзюба // Відповідальність за злочини у сфері господарської діяльності : матеріали наук.-практ. конф. 5-6 жовт. 2005 р. / редкол.: В. В. Сташис [та ін.] ; Нац. юрид. акад. України ім. Я. Мудрого, Їн-т вивчення проблем злочинності Акад. правових наук. - Х.: Кроссроуд, 2006. - С. 54-61.

14. Лихова С.Я. Злочини у сфері реалізації громадянських, політичних та соціальних прав і свобод людини і громадянина (Розділ V Особливої частини КК України): монографія / С. Я.Лихова. - К. : Вид. полігр. центр «Київ. ун-т», 2006. - 573 с.

15. Загородников Н. И. Объект преступления: от идеологизации содержания к естественному понятию / Н. И. Загородников // Проблемы уголовной политики и уголовного права : межвуз. сб. науч. тр. / МВШМ МВД РФ. - M., 1994. - С. 5-22.

16. Энциклопедия уголовного права. Т. 4. Состав преступления. - СПб. : Изд. проф. Малинина, 2005. - 797 с.

17. Гавриш С. Б. Теоретические предпосылки исследования объекта преступлений / С. Б. Гавриш // Право и политика. - 2000. - № 11. - С. 4-15.

18. Емельянов В. П. Концептуальные аспекты исследования объекта преступления / В. П. Емельянов // Право и политика. - 2002. - № 10. - С. 61-72.

19. Таганцев Н. С. О преступлениях против жизни по русскому праву / H. С. Таганцев. - СПб. : Тип. Н. А. Неклюдова, 1870. - 461 с.

20. Белогриц-Котляревский Л. С. Учебник русского уголовного права. Общая и Особенная части / Л. С. Белогрии-Котляревский. - К. ; Петербург; Х. : Юж.-Рус. книгоизд-во Ф. А. Иогонсона, 1903. - 618 с.

21. Спасович В. Учебник уголовного права. Т. 1 / В. Спасович. - СПб. : Тип. Иосафата: Огризко, 1863. - 428 с.

22. Сергиевский Н. Д. Русское уголовное право. Часть общая: пособие к лекциям / Н. Д. Сергиевский. - СПб., 1911. - VIII, 397 с.

23. Таганцев Н. С. Русское уголовное право: лекции. Часть общая. Т. 1 / H. С. Таганиев. - М., 1994. - 380 с.

24. Шершеневич Г. Ф. Общая теория права / Г. Ф. Шершеневич. - М. : Изд. бр. Башмановых, 1911. - 805 с.

25. Фейербах П. А. Уголовное право. Кн. 1. Философская или всеобщая часть уголовного права / П. А. Фейербах. - СПб. : Мед. тип., 1810. - С. 11-142.

26. Бойцов А. И. Преступления против собственности / А. И. Бойщов. - СПб. : Юрид. центр Пресс, 2002. - 775 с.

27. Курс советского уголовного права. Часть общая. Т. 1. - Ленинград: Изд-во Ленингр. ун-та, 1968. - 645 с.

28. Иеринг Р. Цель в праве. Т. 1 / Р. Иеринг; под ред. В. Р. Лицкой ; пер.: Н. Ф. Дерюжинский, Н. В. Муравьев. - СПб., 1881.

29. Дурманов Н. Д. Понятие преступления / Н. Д. Дурманов. - М. : Изд-во Акад. наук СССР, 1948. - 311 с.

30. Жалинский А. Э. Уголовное право в ожидании перемен: теоретико-инструментальный анализ / А. Э. Жалинский. - 2-е изд., перераб. и доп. - М. : Проспект, 2009. - $400 \mathrm{c}$.

31. Общетеоретическая юрисдикция : учеб. курс : учебник / под ред. Ю. Н. Оборотова. - О.: Феникс, 2011. - 436 с.

32. Хозяйственное право Украины : учебник / под ред. А. С. Васильева, О. П. Подцерковного. - 3-е изд., перераб. и доп. - Х. : Одиссей, 2008. - 488 с. 
33. Кримінальне право України. Особлива частина : підруч. для студ. юрид. вузів і ф-тів / Г. В. Андрусів, П. П. Андрушко В. В. Беньківський [та ін.]; за ред. П. С. Матишевського [та ін.]. - К. : Юрінком інтер, 1997. - 896 с.

34. Налуцишин В. В. Кримінальна відповідальність за хуліганство (ст. 296 КК України) : монографія / В. В. Налущцишин. - Х. : Харків юрид., 2009. - 252 с.

35. Білоконєв В. Чому злочин заподіює шкоду? Спірні питання кримінального права / В. Білоконєв // Закон і бізнес. - 1999. - № 32. - С. 14.

36. Трубников В. М. Кримінальна відповідальність за злісну непокору вимогам адміністрації виправної установи : монографія / В. М. Трубников, Ю. В. Орел. - Х. : Харків юрид., 2009. - 356 с.

37. Шапп Я. О. О свободе, морали и праве / Я. О. Шапn // Государство и право. 2002. - № 5. - C. 85-92.

38. Абрашкевич М. М. Прелюбодеяние с точки зрения уголовного права: историко-догматическое исследование / М. М. Абрашкевич. - О.: Экон. тип., 1904. - 640 с.

39. Проблеми сучасної конституціоналістики : навч. посіб. / M.П.Орзіх, М. В. Афанасьєва, В. Р. Барський [та ін.] ; за ред. М. П. Орзіха. - К. : Юрінком інтер, 2011. - 272 с.

40. Гавриш С. Б. Кримінально-правова охорона довкілля в України. Проблеми теоріі, застосування і розвитку кримінального законодавства / С. Б. Гавриш. - K., 2002.$634 \mathrm{c.}$

41. Довкілля як об’єкт кримінально-правової охорони : навч. посіб. / C. В. Діденко, С. В. Крючек, Г. С. Поліщук, Ю. В. Біла, В.О.Миронова. - Х. : Харків юрид., 2009. - $184 \mathrm{c}$.

42. Киричко В. М. Злочини у сфері господарської діяльності за кримінальним кодексом України та в судовій практиці : наук.-практ. комент. / B. M. Киричко, O. I. Перепелиця ; за заг. ред. В.Я. Тація. - Х. : Право, 2010. - 784 с.

43. Гражданский кодекс Украины : науч.-практ. коммент. / под ред. Е. О. Харитонова. Изд. 4-е, доп. и перераб. - Х. : Одиссей, 2007. - 1280 с.

44. Векленко В. В. Преступления против собственности как уголовно-правовая фикция / В. В. Векленко // Российский юридический журнал. - 2000. - № 3. - С. 12-17.

45. Есаков Г. А. Уголовное право зарубежных стран / Г. А. Есаков, Н. Е. Крылова, A. В. Серебренникова. - М. : Проспект, 2009. - 336 с.

46. Харитонов Е.О. Гражданское право Украины: учебник / E. O. Харитонов, А. В. Стариев, Е. И. Харитонова. - Изд. 3-е, перераб. и доп. - Х. : Одиссей, 2007. $920 \mathrm{c}$.

47. Майданник О. О. Конституційне право України : навч. посіб. / О. О. Майданник. К. : Алетра, 2011. - 380 с.

48. Николаева Ю.В. Преступления против мира и безопасности человечества / Ю. В. Николаева. - М. : Наука, 1999. - 364 с.

49. Курс уголовного права. В 5 т. Т. 5. Особенная часть / под ред. Г. Н. Борзенкова, В. С. Комиссарова. - М. : Зерцало, 2002. - 512 с.

50. Уголовное право. Особенная часть. Т. 2 / Под ред. Л.Д. Гаухмана, С.В. Максимова. - M., 1999

51. Кибальник А. Г. Преступления против мира и безопасности человечества / А. Г. Кибальник, И. Г. Соломоненко ; под ред. А. В. Наумова. - СПб. : Юрид. центр Пресс, 2004. - 385 c.

52. Вісник Конституційного Суду України. - 2004. - № 5. - С. 38-45.

53. Скакун О.В. Теория государства и права (энциклопедический курс) : учебник / О. В. Скакун. - Х. : Эспада, 2007. - 840 с.

54. Теліпко В. Є. Науково-практичний коментар Конституції України / B. E. Теліпко ; за ред. В. Л. Мусіяки. - К. : Центр учб. л-ри, 2011. - 544 с. 


\section{А н нот а ци я}

Чугуников И.И. Объект преступления в современной уголовно-правовой науке: традиции и новации. - Статья.

В статье анализируется современный этап развития уголовно-правового учения об объекте преступления, характеризующийся масштабной ревизией традиционных представлений об этом элементе состава преступления как охраняемых законом об уголовной ответственности общественных отношениях. Рассматриваются предложенные в современной науке трактовки объекта как правового блага, социальной ценности, человека, его прав и свобод. Делается вывод о том, что вне определенного социального порядка эти категории лишены какой-либо функциональной нагрузки, а предложения, связанные с отказом от использования в уголовно-правовой теории понятия «общественные отношения», чаще всего продиктованы соображениями сугубо идеологического, а порою и конъюнктурного характера. На основе действующего уголовного законодательства Украины предпринимается попытка доказать жизнеспособность традиционного для отечественной уголовно-правовой науки подхода к определению понятия объекта преступления.

Ключевые слова: объект преступления, общественные отношения, правовое благо, социальная ценность, человек, права и свободы человека.

\section{А н о т а ці я}

Чугуников $\dot{I} \dot{I}$. Об'єкт злочину у сучасній кримінально-правовій науці: традиції та новації. - Стаття.

У статті аналізується сучасний етап розвитку кримінально-правового вчення про об’єкт злочину, який характеризується масштабною ревізією традиційних уявлень щодо цього елемента складу злочину як охоронюваних законом про кримінальну відповідальність суспільних відносинах. Розглядаються запропоновані у сучасній науці трактовки об’єкта як правового блага, соціальної цінності, людини, іiї прав та свобод. Робиться висновок про те, що поза певним соціальним порядком ці категорії позбавлені будьякого функціонального навантаження, а пропозиції, пов'язані з відмовою від використання у кримінально-правовій теорії поняття «суспільні відносини», найчастіше за все обумовлені міркуваннями суто ідеологічного, а подекуди й кон'юнктурного характеру. На підставі діючого кримінального законодавства України робиться спроба довести життєздатність традиційного для вітчизняної кримінально-правової науки підходу до визначення поняття об’єкта злочину.

Ключові слова: об’єкт злочину, суспільні відносини, правове благо, соціальна цінність, людина, права і свободи людини.

\section{S u m m a r y}

Chugunnikov I.I. Object of crime in modern criminal and legal science: traditions and innovations. - Article.

Modern stage of development of criminal and legal doctrine on object of crime, characterized by extensive revision of traditional notions on this element of crime components as protected by law on criminal responsibility in social relations, has been analyzed in the article. Offered in modern science representations of the object as legal benefit, social value of a human, human rights and freedoms, have been examined. It has been concluded that outside specific social order these categories lack any functional load, and offers connected with refusal from use of notion «social relations» in criminal and legal theory are more often caused by considerations of absolutely ideological and sometimes even conjuncture nature. On the ground of effective criminal legislation of Ukraine an attempt to prove feasibility of traditional for native criminal and legal science approach to defining the notion of object of crime has been made.

Keywords: object of crime, social relations, legal benefit, social value, human, human rights and freedoms. 